\title{
USE of Some Essential Oils as Safe Alternatives to Conserve Peach Fruits Quality During Shelf Life
}

\author{
Gehan A. Mahmoud* and Hemat S. Abd El-Salam ${ }^{* *}$ \\ ${ }^{*}$ Fruit Handling Research Department ${ }^{* *}$ Medicinal and \\ **A Aromatic Plant Research Department, Horticulture Research \\ Institute, Agricultural Research Centre, Cairo, Egypt.
}

\begin{abstract}
7 HIS STUDY aimed to evaluate the potential application of essential oils of celery, cinnamon and coriander to determine the antifungal effects of the essential oils against grey mould disease of peach fruits and control postharvest decay under shelf conditions. Three concentrations $(600,800$ and $1000 \mathrm{ppm})$ of the tested essential oils were applied. Chemical composition of the essential oils were identified by GC-MS. Results showed that all of these essential oils application significantly decreased weight loss and decay percentage and increased fruit shelf -life. Also, essential oils, positively, affected postharvest quality factors including total soluble solids, titratable acidity, total soluble sugars and total soluble pectin. It was observed that celery essential oil gave the best effect on the treated fruits followed in a descending order by cinnamon then coriander compared to control.
\end{abstract}

Peach (Prunus persica L.) is one of the most important fruits all over the World. Peaches are highly demanded by the Egyptian consumers. Total area cultivated of peach and nectarines in Egypt amounted to 333487 tons according to the statistics of FAO (2012).

Peaches are susceptible to postharvest decay caused by several pathogenic fungi such as Botrytis cinerea, which is one of the major disease of peach. Botrytis cinerea (grey mould rot) is a ubiquitous pathogen, causes severe damage in many fruits, vegetables and ornamental crops in pre- and postharvest (Mohammadi and Aminifard, 2012). In nature, essential oils play an important role in plant protection i.e. antibacterial, antiviral, antifungal, insecticides and also against herbivores by reducing their appetite for such plants (Bakkali et al., 2008, Isman, 2000 and Burt, 2004). The plant essential oils antimicrobial mode of action' is vary and is still not fully understood (Burt, 2004). However, it could happen through several ways including cell wall deterioration, cytoplasmic membrane injury and leakage of cell contents, membrane protein damage, cytoplasm coagulation, depletion of proton motive force sites, inactivation of essential enzymes and disturbance of DNA and RNA (Burt, 2004 and AyalaZavala et al., 2008). The volatile oil in celery has been shown to have antifungal activity (Sipailiene et al., 2005). The main constituents in the oil of Apium graveolens were limonene, carvone and 3-n-butylphthalide, phthalides, $\beta$ selinene, giaveobisides and fatty oil (Amin and Sleem, 2007). Gill and Holly (2004) proposed that cinnamic aldehyde could inhibit the energy metabolism by 
depleting ATP in cells, without disturbing the cell membrane. On the other hand, Gupta et al. (2008) proposed that the high electronegative nature of cinnamic aldehyde could interfere the biological process by reacting with nucleic acid, proteins, impede the electron transfer and hence, inhibit the growth of microbes. The antifungal activity of the essential oil of Coriandrum sativum fruits may be attributed to its main constituents, linalool (58.22\%) and geraniol (17.87\%). Previous studies of the chemical composition of $C$. sativum fruit essential oil carried out by Pino et al. (1996) and Burt (2004) reported that linalool concentrations were $54.57 \%$ and $70 \%$, respectively. Antimicrobial activity of linalool against several bacteria and fungi has also been reported (Pattnaik et al., 1997 and Delaquis et al., 2002). Essential oils mainly conjugated to phenolic compounds that accumulate in some plant cells and show useful effect for pathogen control (Plotto et al., 2003). The oxidation products of phlorsidzin (an ortho-dihidroxyphenolic compound) inhibit growth the apple scab fungus Venturia inaequalsi. Fungal pectinases hydrolyze pectin, a cell wall compound that is abundant in the middle lamella and plays a role in cell adhesion. Thus, by inhibiting pectinases, the ability of the fungus to hydrolyze and invade the plant cell wall would be compromised (Vermerris and Nicholoson, 2006).

Due to the above mentioned information, this work aimed to control post harvest decay of peach fruits, elongating its market period by spraying fruits with essential oils of celery, cinnamon and coriander.

\section{Materials and Methods}

Mature peach fruits of 104 days age from full bloom were picked from a private farm located on Cairo Alex. Desert road in (2012-2013). The fruits were immediately transported to the laboratory, cleaned and packed in perforated carton boxes. Three replicates from each treatment were used for fruit physical and chemical properties determination, sprayed with three concentrations (600, 800 and $1000 \mathrm{ppm}$ ) of celery, cinnamon and coriander essential oils and left at ambient temperature $\left(20-30^{\circ} \mathrm{C}\right)$ for 12 days.

\section{Separation of Essential Oils}

Essential oils of celery oil (Apium graveolens), cinnamon oil (Cinnamomum zeylanicum) and coriander oil (Coriandrum sativum) were separated by hydrodistillation according to Guenther (1950). The pure volatile oil was injected in Gas Chromatograph Mass Spectrometer (GCMS) model Schimadzu QP-5000 equipped with DB-1 column $(30 \mathrm{~m} \times 0.25 \mathrm{~mm} \times 0.250$ Micron film thickness $)$ according to Boniface et al. (2012).

\section{Inhibition zone of grey mould}

The fungi of Botrytis cinerea (grey mould) was grown in petri dishes on potato dextrose agar (pda) medium. The test were repeated on three replicates for two days per treatment [600, 800 and $1000 \mathrm{ppm}$ ] for each essential oil (Dhingra and Sinclair, 1985). 
Fruit keeping quality under shelf conditions

In each treatment, different measurements were carried out starting from zero-time of shelf-life and continued at intervals of 4 days till the end of 12 days.

\section{Physical Characteristics}

Fruit decay (\%)

Fruits which were decayed by different physiological and pathological factors were periodically counted and discarded, and then percentage of fruit decay was calculated in relation to the total number of fruits.

Loss in fruit weight (\%)

Fruits were periodically weighed and loss in fruit weight was recorded for each replicate and then it was calculated as percentages in relation to the fruits weight at zero time of shelf-life.

\section{Chemical characteristics}

Determination of Acidity \%

Total acidity as gm of anhydrous citric acid determined and estimated per $100 \mathrm{ml}$ fruit juice, according to A.O.A.C. (1990).

Total soluble solids percentages (T.S.S.)

It was measured in juice using the Hand Refractometer.

\section{Total soluble pectin}

Pectic substances were determined as $\mathrm{gm} / 100 \mathrm{gm}$ dry weight according to the procedure of Aina et al. (2012).

\section{Total soluble sugars}

Colorimetric determination of total soluble sugars expressed as glucose was determined according to Dubois et al. (1956).

\section{Statistical analyses}

The obtained data were analyzed according to the method of Duncan (1955). Means were compared using L.S.D. values at 5\% level. Means followed by the same letter are not statistically different.

\section{Results and Discussion}

Fractionation and identification of celery, cinnamon and coriander essential oils

Essential oil components of celery oil (Apium graveolens), cinnamon oil (Cinnamomum zeylanicum) and coriander oil (Coriandrum sativum) are presented in Table 1. 
TABLE 1. Fractionation of celery, cinnamon and coriander essential oils by GCMS.

\begin{tabular}{|c|c|c|c|c|}
\hline \multirow{2}{*}{ No } & \multirow{2}{*}{ Compound name } & \multicolumn{3}{|c|}{ Peak area $(\%)$} \\
\hline & & Celery oil & Cinnamon oil & Coriander oil \\
\hline 1 & $\alpha$-pinene & 7.4 & 5.14 & 6.21 \\
\hline 2 & $\beta$-pinene & 9.75 & 4.99 & 2.17 \\
\hline 3 & Myrcene & 4.24 & 3.65 & 4.54 \\
\hline 4 & $\alpha$-terpinene & 0.02 & --- & 2.07 \\
\hline 5 & $\gamma$-Terpinene & --- & --- & 6.3 \\
\hline 6 & $\delta$ - terpinene & --- & 0.9 & --- \\
\hline 7 & p-cymene & 4.54 & 2.65 & 2.38 \\
\hline 8 & Limonene & 36.76 & 4.7 & 5.19 \\
\hline 9 & Camphor & --- & 1.43 & 7.22 \\
\hline 10 & 1,8 cineole & --- & -- & 3.54 \\
\hline 11 & Linalool & 3.2 & --- & 48.43 \\
\hline 12 & Geraniol & 0.74 & 0.09 & --- \\
\hline 13 & Geranyl acetate & 11.8 & -- & 9.54 \\
\hline 14 & Apiol & 6.45 & --- & -- \\
\hline 15 & Citronellol & 0.96 & --- & --- \\
\hline 16 & $\beta$-Ocimene & 6.7 & --- & --- \\
\hline 17 & Terpineol & 4.24 & 5.23 & --- \\
\hline 18 & $\beta$-Caryophyllene & 5.4 & --- & --- \\
\hline 19 & $\alpha$-phellandrene & --- & 4.11 & --- \\
\hline 20 & Cinnamicaldehyde & --- & 54.65 & --- \\
\hline 21 & Citronellal & --- & --- & 2.41 \\
\hline 22 & Thymol & --- & 7.23 & --- \\
\hline 23 & Caryophyllene & --- & 5.32 & --- \\
\hline
\end{tabular}

Data revealed that the main component of celery oil was limonene which recorded $36.76 \%$. Moreover, the oil contained geranyl acetate, $\beta$-pinene, $\alpha$ pinene, $\beta$-ocimene and apiol which recorded $11.8,9.75,7.4,6.7$ and $6.45 \%$, respectively.

Moreover, data demonstrated that the main component of cinnamon oil was cinnamic aldehyde which recorded $54.65 \%$. The oil, also, contained thymol (7.23\%), caryophyllene (5.32\%), terpineol (5.23\%), $\alpha$-pinene (5.14\%), $\beta$-pinene (4.99\%), limonene (4.7\%), $\alpha$-phellandrene $(4.11 \%)$ and myrecene $(3.65 \%)$.

Furthermore, data showed that the main component of coriander oil was linalool which recorded $48.43 \%$. The oil contained geranyl acetate $(9.54 \%)$, camphor (7.22\%), $\gamma$-terpinene $(6.3 \%), \alpha$-pinene $(6.21 \%)$, limonene $(5.19 \%)$, myrecene $(4.54 \%)$ and 1,8 cineole $(3.54 \%)$.

Results are in agreement with Dauksas et al. (2002) who stated that the limonene is the main component in celery oil. 
Effect of celery, cinnamon and coriander essential oils on inhibition zone of grey mould disease (Botrytis cinerea):

The results presented in Table 2 show that celery, cinnamon and coriander oil in most cases inhibited fungi growth in the test cultures.

TABLE 2. Effect of celery, cinnamon and coriander essential oils on inhibition zone diameter of Botrytis cinerea (grey mould) after 2 days.

\begin{tabular}{|c|c|c|}
\hline \multirow{2}{*}{ Plant } & $\begin{array}{c}\text { Concentration } \\
(\mathbf{p p m})\end{array}$ & $\begin{array}{c}\text { Diameter of inhibition zone } \\
(\mathbf{m m})\end{array}$ \\
\hline Control & --- & 0.0 \\
\hline \multirow{3}{*}{ Celery } & 600 & 17 \\
\cline { 2 - 3 } & 800 & 28 \\
\cline { 2 - 3 } & 1000 & 31 \\
\hline \multirow{3}{*}{ Cinnamon } & 600 & 20 \\
\cline { 2 - 3 } & 800 & 16 \\
\cline { 2 - 3 } & 1000 & 25 \\
\hline \multirow{2}{*}{ Coriander } & 600 & 10 \\
\cline { 2 - 3 } & 800 & 14 \\
\cline { 2 - 3 } & 1000 & 15 \\
\hline
\end{tabular}

Diameter of inhibition zone $(\mathrm{mm})$ resulted from the application by three concentrations of essential oils recorded that celery oil at the tested concentrations (800 and $1000 \mathrm{ppm}$ ) inhibited the growth of Botrytis cinerea (grey mould) more than any other applications.

The results of the present study are similar to that obtained by Sipailiene et al. (2005) who found that chemical composition of celery was active against many bacteria species. Also, Benbelaid et al. (2013) stated that Apium graveolens have an acceptable inhibitory effect on Candida albicans, Bacillus subtilis and Staphylococcus aureus.

Moreover, the antimicrobial activity of cinnamon is mainly due to the presence of cinnamic aldehyde (3-phenyl-2-propenal) (Zaika, 1988, Gill \& Holley, 2004, Ooi et al., 2006, Gupta et al., 2008 and Muthuswamy et al., 2008).

The essential oil of Coriandrum sativum has highest antibacterial activity against the Staphylococcus aureus, Enterobacter aerogenes, Klebsiella pneumonia, Vibrio cholerae and Salmonella typhimerium (Suganya et al., 2012).

The mode of action of natural plant antimicrobials vary and are still not fully understood (Burt, 2004).

In this respect, Burt (2004) and Ayala-Zavala et al. (2009) suggested that natural antimicrobials have several mode of actions including cell wall deterioration, cytoplasmic membrane injury and leakage of cell contents, membrane protein damage, cytoplasm coagulation, depletion of proton motive force sites, inactivation of essential enzymes and disturbance of DNA and RNA. 
Effect of celery, cinnamon and coriander essential oils on postharvest quality factors of peach fruits

Table 3 illustrated the effect of using celery, cinnamon and coriander essential oils on decay and weight loss of peach fruits under shelf life conditions.

Concerning the decay $\%$ in peach fruits under shelf conditions, the highest decay percentage was noticed in the control treatment after 12 days (100\%), however, the lowest decay \% is shown with the use of 600, 800 and $1000 \mathrm{ppm}$ of celery essential oil after 12 days (10\%) as shown in Table 3 and Fig. 1.

Considering weight loss $\%$, it could be concluded that the highest weight loss \% resulted from the control after 12 days $(20.5 \%)$. On the contrary, the lowest weight loss \% was recorded when using celery by $1000 \mathrm{ppm}$ after 12 days (10\%).

TABLE 3. Effect of using celery, cinnamon and coriander essential oils on decay and weight loss of peach fruits under shelf conditions.

\begin{tabular}{|c|c|c|c|c|c|c|c|c|c|}
\hline \multirow{2}{*}{ Treatments } & $\begin{array}{c}\text { Concentration } \\
\text { (ppm) }\end{array}$ & \multicolumn{4}{|c|}{ Decay \% } & \multicolumn{4}{c|}{ Weight loss \% } \\
\cline { 2 - 9 } Control & $\mathbf{0}$ & $\mathbf{4}$ & $\mathbf{8}$ & $\mathbf{1 2}$ & $\mathbf{0}$ & $\mathbf{4}$ & $\mathbf{8}$ & $\mathbf{1 2}$ \\
\hline---- & 0 & 24 & 70 & 100 & 0 & 5.70 & 12.35 & 20.5 \\
& 600 & 0 & 0 & 4 & 10 & 0 & 1.8 & 5.8 & 12.4 \\
Celery & 800 & 0 & 0 & 4 & 10 & 0 & 1.4 & 5.0 & 11.82 \\
& 1000 & 0 & 0 & 6 & 10 & 0 & 2.2 & 4.2 & 10.0 \\
Cinnamon & 600 & 0 & 0 & 8 & 24 & 0 & 3.4 & 6.7 & 12.64 \\
& 800 & 0 & 0 & 8 & 24 & 0 & 3.0 & 6.2 & 12.9 \\
& 1000 & 0 & 0 & 6 & 20 & 0 & 2.5 & 5.0 & 11.08 \\
& 600 & 0 & 8 & 28 & 80 & 0 & 4.8 & 11.09 & 15.2 \\
& 800 & 0 & 8 & 24 & 70 & 0 & 4.2 & 10.52 & 14.8 \\
& 1000 & 0 & 0 & 16 & 62 & 0 & 4.0 & 9.41 & 13.7 \\
\hline
\end{tabular}

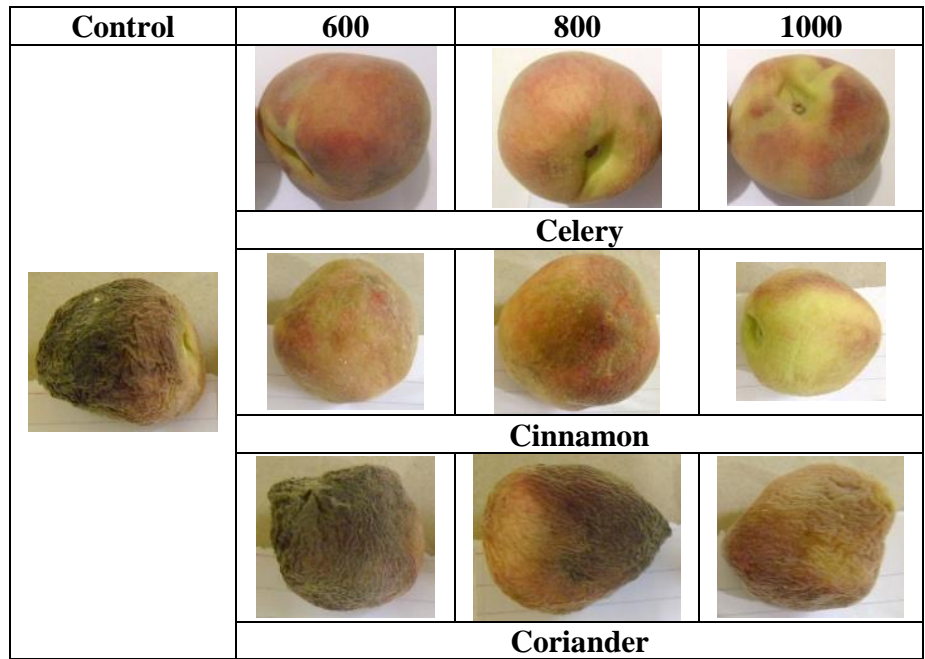

Fig. 1. Effect of celery, cinnamon and coriander essential oils (ppm) on keeping quality of peach fruits after 12 days under shelf conditions.

Egypt. J. Hort. Vol. 41, No. 2 (2014) 
The effect of using celery, cinnamon and coriander, essential oils on acidity $\%$ and T.S.S $\%$ of peach fruits under shelf life conditions are presented in Table 4.

TABLE 4. Effect of using celery, cinnamon and coriander essential oils on acidity \% and T.S.S\% of peach fruits under shelf life conditions.

\begin{tabular}{|c|c|c|c|c|c|c|c|c|c|c|c|}
\hline \multirow{3}{*}{ Treatments } & \multirow{3}{*}{$\begin{array}{c}\text { Concentra } \\
\text { tion } \\
(\mathbf{p p m})\end{array}$} & \multicolumn{10}{|c|}{ Acidity \% and T.S.S \% } \\
\hline & & \multicolumn{5}{|c|}{ Acidity\% } & \multicolumn{5}{|c|}{ T.S.S\% } \\
\hline & & $\mathbf{0}$ & 4 & 8 & 12 & Mean & $\mathbf{0}$ & 4 & 8 & 12 & Mean \\
\hline Control & $-\ldots$ & 0.995 & 0.976 & 0.819 & 0.768 & $0.890 \mathrm{i}$ & 10.07 & 10.39 & 10.62 & 10.78 & $10.465 \mathrm{f}$ \\
\hline \multirow{3}{*}{ Celery } & 600 & 0.996 & 0.997 & 0.865 & 0.832 & $0.923 \mathrm{~d}$ & 10.10 & 10.675 & 10.84 & 10.97 & $10.645 \mathrm{~b}$ \\
\hline & 800 & 0.998 & 0.999 & 0.943 & 0.803 & $0.936 \mathrm{~b}$ & 10.07 & 10.69 & 10.85 & 11.07 & $10.671 \mathrm{ab}$ \\
\hline & 1000 & 0.996 & 0.985 & 0.943 & 0.808 & $0.933 \mathrm{c}$ & 10.07 & 10.70 & 10.81 & 11.12 & $10.675 \mathrm{a}$ \\
\hline \multirow{3}{*}{ Cinnamon } & 600 & 0.996 & 0.980 & 0.843 & 0.800 & $0.905 \mathrm{f}$ & 10.05 & 10.56 & 10.73 & 10.98 & $10.581 \mathrm{c}$ \\
\hline & 800 & 0.994 & 0.993 & \begin{tabular}{|l|l|}
0.859 \\
\end{tabular} & 0.800 & $0.912 \mathrm{e}$ & 10.08 & 10.52 & 10.72 & 10.85 & $10.542 \mathrm{~d}$ \\
\hline & 1000 & 0.995 & 0.975 & 0.843 & 0.804 & $0.904 \mathrm{f}$ & 10.07 & 10.53 & 10.73 & 10.85 & $10.546 \mathrm{~d}$ \\
\hline \multirow{3}{*}{ Coriander } & 600 & 0.994 & 0.973 & 0.821 & 0.780 & $0.892 \mathrm{~h}$ & 10.07 & 10.42 & 10.63 & 10.90 & $10.50 \mathrm{be}$ \\
\hline & 800 & 0.996 & 0.970 & 0.833 & 0.985 & $0.946 \mathrm{a}$ & 10.09 & 10.40 & 10.60 & 10.89 & $10.495 \mathrm{e}$ \\
\hline & 1000 & 0.996 & 0.994 & 0.800 & 0.798 & $0.895 \mathrm{~g}$ & 10.08 & 10.47 & 10.69 & 10.93 & $10.543 \mathrm{~d}$ \\
\hline Mean & & $0.996 \mathrm{a}$ & $0.984 \mathrm{~b}$ & $0.857 \mathrm{c}$ & $0.817 \mathrm{~d}$ & & $10.076 \mathrm{~d}$ & $10.535 \mathrm{c}$ & $10.722 \mathrm{~b}$ & $10.934 \mathrm{a}$ & \\
\hline D.at $5 \%$ & & \multicolumn{5}{|c|}{ For interaction 0.004} & \multicolumn{5}{|c|}{ For interaction $\mathbf{0 . 0 5 2 7}$} \\
\hline
\end{tabular}

Concerning fruit juice acidity \%, results revealed that it is significantly decreased during 12 days for all tested treatments while using coriander oil with concentration of $800 \mathrm{ppm}$ significantly resulted in the highest acidity $\%$ recording $0.946 \%$. The lowest value is obtained with the control $(0.890 \%)$ followed by the application of coriander oil at 600 ppm after 12 days $(0.892 \%)$.

Regarding T.S.S.\%, the results showed significant increase during 12 days. Using celery oil by the concentration of $1000 \mathrm{ppm}$ significantly led to the highest T.S.S. recording $10.675 \%$, however, the control treatment significantly recorded the lowest T.S.S.\% (10.465\%).

The effect of using celery, coriander and cinnamon essential oils on pectin $\%$ and total sugars $\%$ of peach fruits under shelf life conditions are presented in Table 5 .

TABLE 5. Effect of using celery, cinnamon and coriander essential oils on Total soluble Pectin\% and Total soluble sugars\% of peach fruits under shelf life conditions.

\begin{tabular}{|c|c|c|c|c|c|c|c|c|c|c|c|}
\hline \multirow{3}{*}{ Treatments } & \multirow{3}{*}{$\begin{array}{c}\text { Concentration } \\
(\mathbf{p p m})\end{array}$} & \multicolumn{10}{|c|}{ Total soluble Pectin \% and Total soluble sugars\% } \\
\hline & & \multicolumn{5}{|c|}{ Total soluble Pectin \% } & \multicolumn{5}{|c|}{ Total soluble sugars \% } \\
\hline & & $\mathbf{0}$ & 4 & 8 & 12 & Mean & $\mathbf{0}$ & 4 & 8 & 12 & Mean \\
\hline Control & ----- & 1.52 & 1.61 & 1.78 & 1.93 & $1.71 \mathrm{a}$ & 6.96 & 6.89 & 6.91 & 6.94 & $6.923 \mathrm{~h}$ \\
\hline \multirow{3}{*}{ Celery } & 600 & 1.52 & 1.50 & 1.67 & 1.65 & $1.585 \mathrm{f}$ & 6.94 & 7.26 & 7.33 & 7.30 & $7.193 \mathrm{bc}$ \\
\hline & 800 & 1.51 & 1.52 & 1.63 & 1.71 & $1.593 \mathrm{f}$ & 6.94 & 7.30 & 7.32 & 7.33 & $7.202 \mathrm{~b}$ \\
\hline & 1000 & 1.51 & 1.5 & 1.64 & 1.74 & $1.598 \mathrm{f}$ & 6.93 & 7.3 & 7.40 & 7.37 & $7.25 \mathrm{a}$ \\
\hline \multirow{3}{*}{ Cinnamon } & 600 & 1.51 & 1.50 & 1.63 & 1.82 & $1.615 \mathrm{e}$ & 6.91 & 7.16 & 7.21 & 7.27 & $7.098 \mathrm{e}$ \\
\hline & 800 & 1.52 & 1.53 & 1.65 & 1.79 & $1.622 \mathrm{de}$ & 6.95 & 7.22 & 7.25 & 7.26 & $7.148 \mathrm{~d}$ \\
\hline & 1000 & 1.52 & 1.56 & 1.66 & 1.71 & $1.618 \mathrm{e}$ & 6.94 & 7.24 & 7.29 & 7.28 & $7.178 \mathrm{c}$ \\
\hline \multirow{3}{*}{ Coriander } & 600 & 1.51 & 1.47 & 1.66 & 1.92 & $1.645 \mathrm{bc}$ & 6.95 & 6.90 & 6.94 & 6.98 & $6.951 \mathrm{~g}$ \\
\hline & 800 & 1.51 & 1.48 & 1.63 & 1.91 & $1.633 \mathrm{~cd}$ & 6.95 & 6.90 & 6.96 & 6.99 & $6.963 \mathrm{~g}$ \\
\hline & 1000 & 1.52 & 1.51 & 1.67 & 1.90 & $1.65 \mathrm{~b}$ & 6.93 & 6.89 & 7.00 & 7.06 & $6.983 \mathrm{f}$ \\
\hline \multirow{2}{*}{$\begin{array}{l}\text { Mean } \\
\text { L.S.D. } \\
\text { at 5\% }\end{array}$} & & $1.519 \mathrm{c}$ & $1.518 \mathrm{c}$ & $1.662 \mathrm{~b}$ & $1.808 \mathrm{a}$ & & $6.939 \mathrm{~d}$ & $7.078 \mathrm{c}$ & $7.161 \mathrm{~b}$ & $7.178 \mathrm{a}$ & \\
\hline & & \multicolumn{5}{|c|}{ For interaction $\mathbf{0 . 0 2 5 7}$} & \multicolumn{5}{|c|}{ For interaction 0.0321} \\
\hline
\end{tabular}

Egypt. J. Hort. Vol. 41, No. 2 (2014) 
The obtained data showed that total soluble pectin \%, increased gradually during storage period up to 12 days. Results revealed that total soluble pectin\% recorded the highest value for control $(1.71 \%)$, while the lowest value was shown with celery oil at all concentrations.

The data, also, revealed that total soluble sugars $\%$ increased gradually up to 12 days. The highest total soluble sugars could be noticed using celery at 1000 ppm after 12 days $(7.25 \%)$, however the lowest total sugars\% was recorded with the control treatment after 12 days of shelf life $(6.923 \%)$.

In this regard, essential oils had positive effects on storage life by reducing fruit decay. Previous reports indicated that fruit decay was reduced during postharvest treatments with volatile compounds in raspberries (Wang, 2003 and Williamson et al., 2007). Essential oils mainly conjugated to phenolic compounds that accumulate in some plant cells and show useful effect for pathogen control (Plotto et al., 2003). It is known that those oxidations products of phlorsidzin (an orhto-dihidroxyphenolic compound) inhibit the growth of apple scab fungus Venturia inaequalsi. Fungal pectinases hydrolyze pectin (cell wall compound) is abundant in the middle lamella and plays a role in cell adhesion. Thus, by inhibiting pectinases, the ability of the fungus to hydrolyze and invade the plant cell wall would be compromised (Vermerris and Nicholoson, 2006). It seems that similar role was done by phenolic compound of essential oils. Thus, these findings reveal that essential oils may have a positive influence on shelf life and reducing the peach fruits decay. The effect of essential oils on microbial growth has been reported by Nazzaro et al. (2013), who thought it may be the result of phenolic compounds of essential oils that cause the altering of microbial cell permeability by interaction with membrane proteins. Treated fruits with essential oils had more total soluble solids, Total acidity, anthocyanin and carbohydrate content, this study showed that essential oils were effective to maintain fruit quality. Our results are in agreement with previous reports which showed that cinnamon and eucalyptus vapor had significant positive effect on fruit TSS of stored strawberry (Tzortzakis, 2007). Also, Marjanlo et al. (2009) reported that titratable acidity of strawberry infected with grey mould, increased with cumin essential oil application. In addation they indicated that essential oils application significantly decreased weight loss percentage. Previous experiments using natural antifungal compounds (eugenol, thymol and menthol vapors) revealed benefits due to reduced weight loss percentage in sweet cherry (Serrano et al., 2005). Similar results were found with eucalyptus and cinnamon oil in strawberry and tomato on reducing weight loss percentage (Tzortzakis, 2007). In fact, there was a linear correlation between ethylene and damage, and, thus, the fungus were responsible for the majority of ethylene production, a part of the basal level typical of non-climacteric fruits. Accordingly, it has been reported that $B$. cinerea produced greater amounts of ethylene as the concentration of conidia inoculated in vitro or in the climacteric tomato fruit increased. The respiration rate was clearly affected by the dimension of infection (Cristescu et al., 2002).

Egypt. J. Hort. Vol. 41, No. 2 (2014) 


\section{Conclusion}

Essential oils of celery, cinnamon and coriander play an important role in protecting peach fruits against grey mould and maintaining fruit quality during shelf-life thus decreased fruit weight loss and decay percentage.

\section{References}

Aina, V.O., Barau, M.M., Mamman, O.A., Amina, Z., Haruna, H.U., Hauwa, M.S. and Yagana, A.B. (2012) Extraction and characterization of pectin from peels of lemon (Citrus limon), grapefruit (Citrus paradisi) and sweet orange (Citrus sinensis). British Journal of Pharmacology and Toxicology, 3(6), 259-262.

Amin, W.M. and Sleem, A.A. (2007) Chemical and biological study of aerial parts of dill (Apium gravelens), Egyptian J. of Biomedical Sci., 23(1), 73-90.

A.O.A.C. (1990) "Methods of Analysis", $13^{\text {th }}$ ed., Association of official Agricultural Chemical, Washington D.C.

Ayala-Zavala, J.F., Gonzalez-Aguilar, G.A. and del-Toro-Sanchez, L. (2009) Enhancing safety and aroma appealing of fresh-fresh-cut fruits and vegetables using the antimicrobial and aromatic power of essential oils. J. of Food Sci., 74 (7), 84-91.

Ayala-Zavala, J., Oms-Oliu, G., Odriozola-Serrano, I., Gonzalez-Aguilar, G., Alvarez-Parrilla, E. and Martin-Belloso, O. (2008) Preservation of fresh-cut tomatoes using natural antimicrobials. European Food Res. and Tech., 226 (5),10471055 .

Bakkali, F., Averbeck, S., Averbeck, D. and Idaomar, M. (2008) Biological effects of essential oils: A review. Food and Chemistry Toxicology, 46, 446-475.

Benbelaid, F., Abdoune, A.M., Khadir, A. and Bendahou, M. (2013) Drying effect on yield and antimicrobial activity of essential oil. International J. of Medicinal and Aromatic Plants, 3(1), 93-101.

Boniface, Y., Philippe, S., Rose de Lima, H., Jean Pierre, N., Guy Alain, A., Fatiou, T. and S. Dominique (2012) Chemical composition and antimicrobial activities of Cinnamomum zeylanicum Blume dry leaves essential oil against Food-borne pathogens and adulterated microorganisms. International Res. J. of Biological Sci., $1(6), 18-25$.

Burt, S. (2004). Essential oils: their antibacterial properties and potential applications in foods - A review. International J. of Food Microbiology, 94, 223-253.

Cristescu, S.M., De Martinis, D., Hekkert, S.L., Parker, D.H. and Harren, F.J.M. (2002) Ethylene production by Botrytis cinerea in vitro and in tomatoes. Applied environmental microbiology, 68, 5342-5350.

Dauksas, E., Venskutonis, P.R., Sivik, B. and Nillson, T. (2002) Effect of fast $\mathrm{CO}_{2}$ ressure changes on the yield of lovage (Levisticum officinale Koch.) and celery (Apium graveolens L.) extracts. J. of Supercritical Fluids, 22, 201-210. 
Delaquis, P.J., Stanish, K., Girard, B. and Mazza, G. (2002) Antimicrobial activity of individual and mixed fractions of dill, cilantro, coriander and eucalyptus essential oils. International J. of Food Microbiology, 74, 101-109.

Dhingra, O.D., and Sinclair, J.E. (1985) "Basic Plant Pathology Methods", C.R.C. press, Boca Baton, Florida, U.S.A., p. 339.

Dubois, M., Smith, F., Gilles, K.A., Hammilton, J.K. and Robers, P.A. (1956) Colorimetric method to determination of sugars and related substances. Analytical Chemistry, 28 (3), 350-356.

Duncan, D.B. (1955) Multiple range and multiple F tests. Biometrics, 11,1-42.

Food and Agriculture Organization (2012) Available at: http://faoestat.fao.org. Accessed $24^{\text {th }} \mathrm{Feb}$.

Gill, A.O. and Holley, R.A. (2004) Mechanisms of bactericidal action of cinnamic aldehyde against Listeria monocytogenes and of eugenol against L. monocytogenes and Lactobacillus sakei. Applied and Enviro. Microbiology, 70 (10), 5750.

Guenther, E. (1950) "The Essential Oils" $4^{\text {th }}$ ed., Vol. I, II. D. Van Nostrand Co., INC., New York.

Gupta, C., Garg, A.P., Uniyal, R.C. and Kumari, A. (2008) Comparative analysis of the antimicrobial activity of cinnamon oil and cinnamon extract on some food-borne microbes. African J. of Microbiology Res., 2(9), 247-251.

Isman, B.M. (2000) Plant essential oils for pest and disease management. J. of Crop Protection, 19, 603-608.

Marjanlo, A.A., Mostofi, Y., Shoeibi, Sh. and Fattahi, M. (2009) Effect of cumin essential oil on postharvest decay and some quality factors of strawberry. $J$. of Medicinal Plants, 8 (31), 25-43.

Mohammadi, S. and Aminifard, M.H. (2012) Effect of essential oils on postharvest decay and some quality factors of peach (Prunus persica var. Redhaven). J. of Biology Environmental Sci., 6 (17), 147-153.

Muthuswamy, S., Rupasinghe, H.P.V. and Stratton, G. (2008) Antimicrobial effect of cinnamon bark extract on Escherichia coli O157: H7, Listeria innocua and fresh-cut apple slices. J. of Food Safety, 28(4), 534-549.

Nazzaro, F., Fratianni, F., De Martino, L., Coppola, R. and De Feo, V. (2013) Effect of essential oils on pathogenic bacteria . Pharmaceuticals, 6 , 1451-1474.

Ooi, L.S., Li, Y., Kam, S.L., Wang, H., Wong, E.Y. and Ooi, V.E. (2006) Antimicrobial activities of cinnamon oil and cinnamaldehyde from the Chinese medicinal herb Cinnamomum cassia Blume. Amer. J. Chinese Medicine, 34(3), 511522.

Pattnaik, S., Subramanyam, V.R., Bapaji, M. and Kole, C.R. (1997) Antibacterial and antifungal activity of aromatic constituents of essential oils. Microbios J., 89, 39-46.

Egypt. J. Hort. Vol. 41, No. 2 (2014) 
Pino, J.A., Rosado, A. and Fuentes, V. (1996) Chemical composition of the seed oil of Coriandrum sativum L from Cuba. J. of Essential Oil Res., 8, 97-98.

Plotto, A., Roberts, D.D and Roberts, R.G. (2003) Evaluation of plant essential oils as natural postharvest disease control of tomato (Lycopersicon esculentum). Acta Hort., 628, 737- 745 .

Serrano, M., Martinez-Romero, D., Castillo, S., Guillen, F. and Valero, D. (2005) The use of the natural antifungal compounds improves the beneficial effect of MAP in sweet cherry storage. Innovative food Sci. and Emerging Technology, 6, 115-123.

Sipailiene, A., Venskutonis, P.R., Sarkinas, A. and Cypiene, V. (2005) Composition and antimicrobial activity of celery (Apium graveolens) leaf and root extracts obtained with liquid carbon dioxide. Acta Hort., 677, 71-77.

Suganya, S., Bharathidasan, R., Senthilkumar, G., Madhanraj, P. and Panneerselvam, A. (2012) Antibacterial activity of essential oil extracted from Coriandrum sativam (L.) and GC-MS analysis. J. of Chemical and Pharmaceutical Res., 4(3),1846-1850.

Tzortzakis, N.G. (2007) Maintaining postharvest quality of fresh produce with volatile compounds . Innovative Food Scince and Emerging Technologies, 8, 111-116.

Vermerris, W. and Nicholoson, R. (2006) "Phenolic Compound Biochemistry", New York: Springer, p.276.

Wang, C.Y. (2003) Maintaining postharvest quality of raspberries with natural volatile compounds. International J. of Food Science and Technology, 38, 869-875

Williamson, B., Tudzynski, B., Tudzynski, P. and Van Kan, J.A. (2007) Botritiscinerea: the cause of grey mould disease. Molecular Plants Pathology, 8, 561580 .

Zaika, L.L. (1988) Spices and herbs: Their antimicrobial activity and its determination. J. of Food Safety, 9(2), 97-118.

(Received 13/8/2014;

accepted $9 / 10 / 2014$ ) 


\section{إستخدام بعض الزيوت العطرية كبائل أمنة لحفظ ثمار الخوخ أثناء

جيهان أحمد محمود" وهمت سميح عبد السلام"

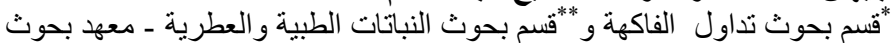
البساتين ـ مركز البحوث الزراعية ـ القاهرة ـ مصر.

تهدف هذه الدراسة إلي تقييم تطبيق إستخدام الكرفس والقرفه والكسبرة لتقدير

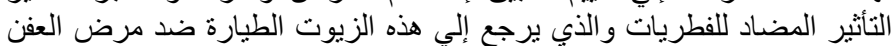

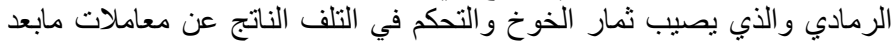

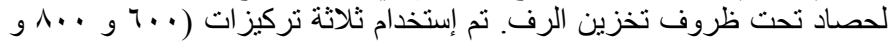

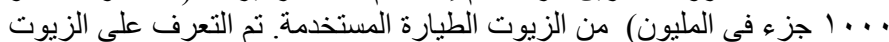

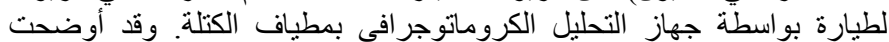

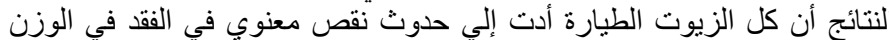

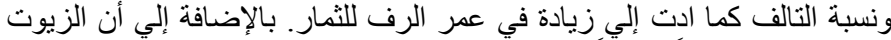

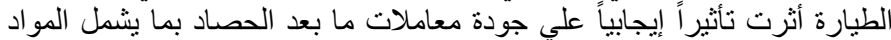

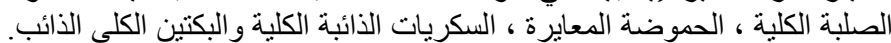

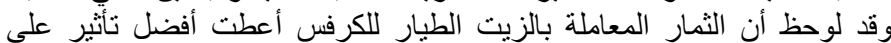

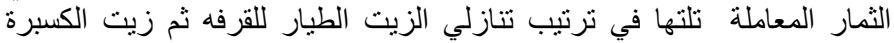

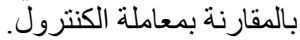

